Jurnal Teknologi Kedirgantaraan, Vol, VII No. 1, Januari 2022, P-ISSN 2528-2778, E-ISSN 2684-9704 https://doi.org/ 10.35894/jtk.v7i1

\title{
Analisis Perbandingan Performa Saat Takeoff Pada Engine Cfm56-7b Dengan Konfigurasi Thrust Rating 26300 LBS Dan 27300 LBS
}

\author{
Defi Setiyawati ${ }^{(1)^{*}}$, Edy K. Alimin ${ }^{(2)}$, Endah Yuniarti(3) \\ (1)(2)(3) Prodi Teknik Penerbangan, Fakultas Teknologi Kedirgantaraan, Universitas \\ Suryadarma Komplek Bandara Halim Perdanakusuma, Jakarta 13610, Indonesia \\ *Corresponding Author: defi.teeya@gmail.com
}

\begin{abstract}
Engine CFM 56-7B merupakan salah satu engine produksi dari CFM International yang dipakai pada pesawat B737-600/700/800/900. Engine ini memiliki beberapa variasi thrust rating dengan performa yang berbeda-beda. Parameter performa engine diantaranya Thrust, Specific Fuel Consumption (SFC), Core Speed (N2), dan Exhaust Gas Temperature (EGT). Pengujian performa dapat dilakukan menggunakan Engine Test Cell. Tetapi engine test cell merupakan calibrated tool, yang memungkinkan terjadi deviasi nilai hasil pengujian. Maka dilakukan perhitungan performa menggunakan rumus yang ada pada Engine Shop Manual - Test 003 - Engine Acceptance Test untuk mengetahui performa engine saat fase takeoff pada thrust rating tertinggi yaitu $26300 \mathrm{lbs}$ dan 27300 lbs serta membandingkan performa kedua engine tersebut. Perbandingan hasil perhitungan menyatakan bahwa engine dengan thrust rating 26300 lbs lebih unggul pada Exhaust Gas Temperature, sedangkan engine dengan thrust rating 27300 lbs mempunyai keunggulan pada Thrust, Specific Fuel Consumption dan Core Speed (N2)
\end{abstract}

keywords: Engine Test Cell, Thrust, Specific Fuel Consumption (SFC), Core Speed (N2), dan Exhaust Gas Temperature (EGT). 


\section{PENDAHULUAN}

Industri penerbangan merupakan bidang industri dengan perkembangan teknologi yang pesat. Salah satunya adalah pengembangan. engine. Manufaktur yang memproduksi engine berlomba-lomba untukmembuat engine dengan teknologi yang mutakhir. Salah satu produsen engine tersebut adalah CFM International.

Produk dari CFM International banyak digunakan untuk mendukung operasi pesawat komersial. Salah satu engine pesawat buatan CFM yang banyak digunakan adalah CFM56-7B. Engine tersebut digunakan pada pesawat Boeing B737600/700/800/900 untuk memenuhi permintaan pasar, CFM melakukanbanyak pengembangan untuk engine CFM56-7B. Oleh karena itu, CFM56-7B memiliki beberapa thrust rating.

Pada penelitian ini, penulis menghitung performa mesin CFM56-7B dengan thrust rating tertinggi yaitu 26300 lbs dan 27300 lbs menggunakan rumus yang adapada Engine Shop Manual Test 003 - Engine Acceptance Test. Kemudian membandingkan performa engine CFM56-7B dengan thrust rating 26300 Ibs dan 27300 lbs dari hasil perhitungan performa tersebut.

\section{TINJAUAN LITERATUR}

Pada mesin turbin gas untuk menghasilkan ekspansi melalui turbin, rasio tekanan sangat dibutuhkan dan langkah pertamayang harus dilakukan dalam siklus instalasi gas turbin adalah mengkompresi fluida melaluikompresor. Setelah fluida dikompresi maka fluida tersebut akan diperluas langsung ke turbin, tidak ada kerugian yang dialami kompresor dan turbin karena gaya yang dikembangkan oleh turbin sama seperti gaya yang diserap oleh kompresor. Tetapi gaya yang masuk ke turbin dapat dikembangkan dengan meningkatkan energi sebelum ekspansi. Ketika fluida kerja adalahudara, cara yang sangat cocok untuk meningkatkan energi adalah dengan cara pembakaran bahan bakar dengan udara yang telah dikompresi. Perluasan fluida kerja panas kemudian menghasilkan output gaya yang lebih besar dari turbin, sehingga mampu memberikan hasil yang bermanfaat selain untuk menggerakkan kompresor. Tiga komponen utama adalah kompresor, ruang bakar dan turbin, seperti yang ditunjukkan pada Gambar 1 di bawah ini. ${ }^{[1]}$

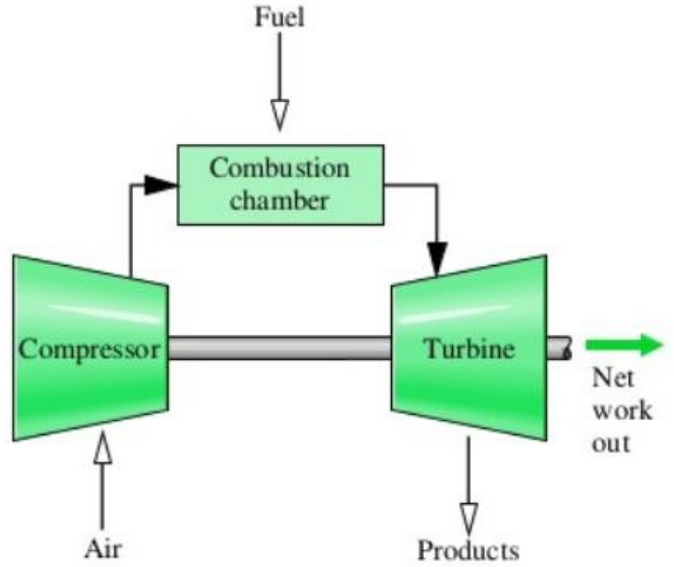

Gambar 1 Sistem turbin gassederhana ${ }^{[2]}$

Siklus thermodinamika turbin gas merupakan suatu mesin yang bekerja mengikuti siklus termodinamik Brayton. Siklus termodinamika pada diagram $P-V$ dan $T$-S adalah sebagai berikut:
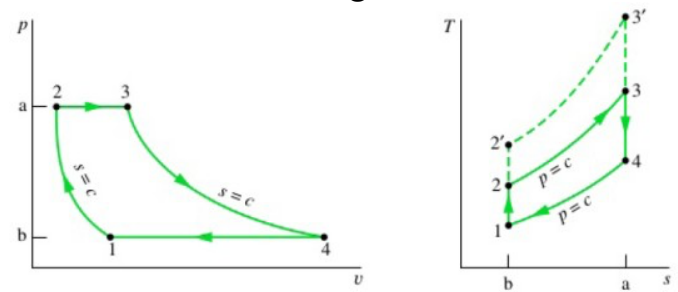

Gambar 2 Siklus turbin gas tekanan konstan ${ }^{[2]}$

Siklus ideal dari system gas turbin sederhana terdiri dari proses:

- 1 - 2 : Proses kompresi isentropic dalam kompresor. 
- $2-3$ : Proses pemasukan kalor pada tekanan $\mathrm{P}$ konstan.

- $3-4$ : Proses ekspansi isentropic dalam turbin.

- $4-1$ : Proses pembunangan kalor tekanan konstan dalam alat pemindah kalor (pendingin).

III. METODOLOGI PENELITIAN

\subsection{Lokasi Penelitian}

Lokasi penelitian adalah di unit Engine Test Cell bagian dari Dinas Engine Maintenance PT.GMF AeroAsia, Tbk

\subsection{Jenis dan Pendekatan \\ Penelitian}

Penelitian ini adalah penelitian kuantitatif yaitu melakukan pengumpulan data berdasarkan pengukuran dan penghitungan yang dilakukan dalam penelitian ini yang hasil daripengukuran dan penghitungan ini diselesaikan secara matematis. Pendekatan penelitian yang bersifat obyektif, mencakupperhitungan dan analisis data kuatitatif. Metode ini digunakan untuk mendapatkan data dari tempat tertentu secara alami. Peneliti menghitung dan membandingkan hasil perhitungan dengan data yang ada di Test Cell.

\subsection{Metode dan Teknik \\ Pengumpulan Data}

Pengumpulan data merupakan langkah yang sangat penting dalam melakukan kajian ilmiah. Metode yang digunakan dalam pengumpulan data sangat mempengaruhi keakuratannya suatu data. Data-data tersebut diperoleh dari hasil perhitungan, literatur maupun wawancara yang kemudian dianalisa menjadi sebuah data deskriptif.

\subsection{Alur Penelitian}

Gambar 3 adalah gambar diagram alur penelitian yang dijadikan sebagai acuan pelaksanaan penelitian

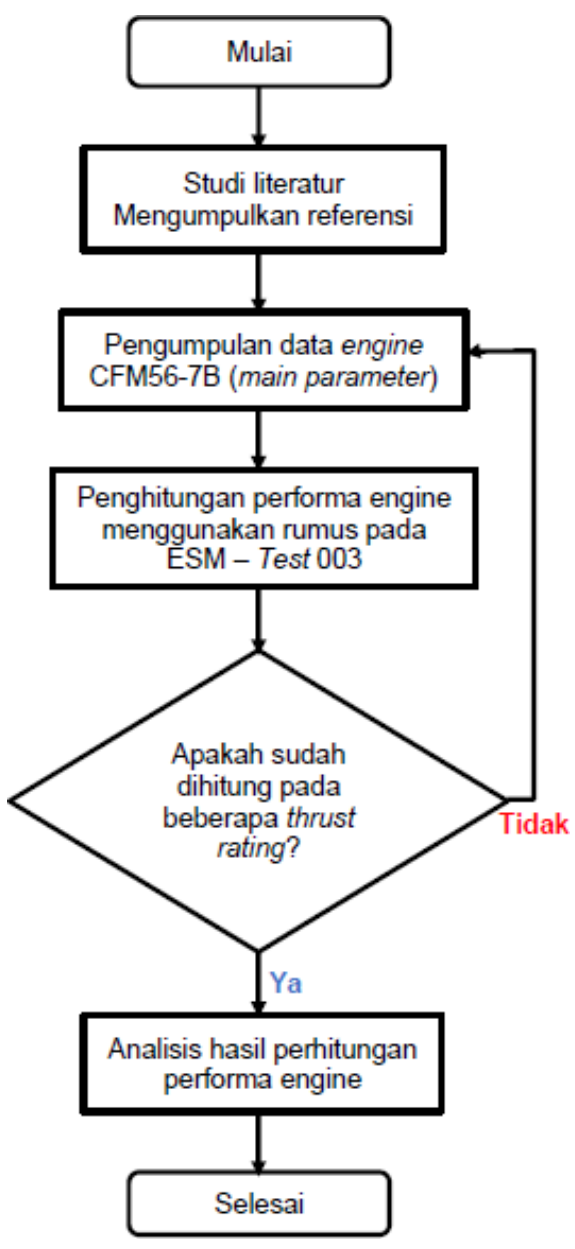

Gambar 1 Alur Penelitian

\section{HASIL DAN PEMBAHASAN \\ 4.1 Perhitungan Performa pada Kondisi takeoff}

\subsubsection{Parameter Engine}

Berdasarkan Hasil Test Cell

Berikut adalah main parameter pada engine CFM56-7Bdengan Serial Number XXX679. Data ini didapat dari hasil test cell pada thrust rating $26300 \mathrm{lbs}$ dan $27300 \mathrm{lbs}$. 
Jurnal Teknologi Kedirgantaraan, Vol, VII No. 1, Januari 2022, P-ISSN 2528-2778, E-ISSN 2684-9704 https://doi.org/ 10.35894/jtk.v7i1

Tabel 1 Data Main Parameter

\begin{tabular}{|c|c|c|c|c|}
\hline \multirow[b]{2}{*}{ No. } & \multirow[b]{2}{*}{ Parameter } & \multicolumn{2}{|c|}{ Value } & \multirow[b]{2}{*}{ Unit } \\
\hline & & $\begin{array}{l}26300 \\
\text { lbs }\end{array}$ & \begin{tabular}{|l}
27300 \\
lbs
\end{tabular} & \\
\hline 1 & N1 045 & 5228 & 5326 & rpm \\
\hline 2 & N2 344 & 14666 & 14642 & $\mathrm{rpm}$ \\
\hline 3 & HUM & 99.6 & 114.0 & grains/lb \\
\hline 4 & Rel HUM & 53.5 & \begin{tabular}{|l|}
92.9 \\
\end{tabular} & $\%$ \\
\hline 5 & WF Main & 10584.3 & \begin{tabular}{|l|}
11265.9 \\
\end{tabular} & \begin{tabular}{|l}
$\mathrm{lb} / \mathrm{hr}$ \\
\end{tabular} \\
\hline 6 & WF Verify & 10584.5 & 11247.1 & $\mathrm{Ib} / \mathrm{hr}$ \\
\hline 7 & EGT/T 495 & 875.0 & 880.3 & ${ }^{\circ} \mathrm{C}$ \\
\hline 8 & $T_{2}$ & 29.61 & 22.78 & ${ }^{\circ} \mathrm{C}$ \\
\hline 9 & $\mathrm{~T}_{25}$ & 131.47 & 129.02 & ${ }^{\circ} \mathrm{C}$ \\
\hline 10 & $T_{3}$ & 582.6 & 581.0 & ${ }^{\circ} \mathrm{C}$ \\
\hline 11 & BARO & 14.679 & 14.672 & psia \\
\hline 12 & $\mathrm{PT}_{2}$ & 14.622 & 14.618 & psia \\
\hline 13 & PS2W & 11.106 & 10.862 & psia \\
\hline 14 & $\mathrm{PT}_{495}$ & 64.793 & 67.660 & psia \\
\hline 15 & PS3 & 396.668 & \begin{tabular}{|l|l|}
417.009 \\
\end{tabular} & \begin{tabular}{|l|} 
psia \\
\end{tabular} \\
\hline 16 & $\mathrm{FN}$ & 25530 & 26774 & Ibs \\
\hline 17 & LHV & 18593 & 18581 & btu/lb \\
\hline
\end{tabular}

\subsubsection{Faktor Koreksi}

Temperature Correction Factor

Tabel 2 Temperature Correction Factor

\begin{tabular}{|c|c|c|}
\hline \multirow{2}{*}{$\begin{array}{c}\text { Correction } \\
\text { Factor }\end{array}$} & \multicolumn{2}{|c|}{ Thrust Rating } \\
\cline { 2 - 3 } & $\mathbf{2 6 3 0 0} \mathbf{~ l b s}$ & $\mathbf{2 7 3 0 0} \mathbf{~ b s}$ \\
\hline $\mathrm{T}_{2}$ & $29.61^{\circ} \mathrm{C}$ & $22.78^{\circ} \mathrm{C}$ \\
\hline$\theta_{2}$ & 1.051 & 1.027 \\
\hline $\mathrm{T}_{25}$ & $131.47^{\circ} \mathrm{C}$ & $129.02^{\circ} \mathrm{C}$ \\
\hline$\theta_{25}$ & 1.404 & 1.396 \\
\hline
\end{tabular}

Pressure Correction Factor

Tabel 3 Pressure Correction Factor

\begin{tabular}{|l|l|l|}
\hline \multirow{2}{*}{$\begin{array}{c}\text { Correction } \\
\text { Factor }\end{array}$} & \multicolumn{2}{|c|}{ Thrust Rating } \\
\cline { 2 - 3 } 22 $^{2}$ & 0.9700 lbs & $\mathbf{2 7 3 0 0}$ lbs \\
\hline PT2/PS2W & 1.31658 & 0.97655 \\
\hline BMCFWX & 0.9792 & 1.34579 \\
\hline
\end{tabular}

Pressure Correction Factor

Tabel 3 Pressure Correction Factor

\begin{tabular}{|l|l|l|}
\hline \multirow{2}{*}{$\begin{array}{c}\text { Correction } \\
\text { Factor }\end{array}$} & \multicolumn{2}{|c|}{ Thrust Rating } \\
\cline { 2 - 3 } & $\mathbf{2 6 3 0 0}$ lbs & $\mathbf{2 7 3 0 0}$ lbs \\
\hline$\delta_{2}$ & 0.97682 & 0.97655 \\
\hline PT2/PS2W & 1.31658 & 1.34579 \\
\hline BMCFWX & 0.9792 & 0.9806 \\
\hline
\end{tabular}

Humidity Correction Factor

Tabel 4 Humidity Correction Factor

\begin{tabular}{|c|l|l|}
\hline \multirow{2}{*}{$\begin{array}{c}\text { Correction } \\
\text { Factor }\end{array}$} & \multicolumn{2}{|c|}{ Thrust Rating } \\
\cline { 2 - 3 } Humidity & $\begin{array}{l}\mathbf{2 6 3 0 0} \text { lbs } \\
\text { grains/lb }\end{array}$ & $\begin{array}{l}\mathbf{2 7 3 0 0} \text { lbs } \\
\text { grains/lb }\end{array}$ \\
\hline KHN1 & 0.99566 & 0.99595 \\
\hline KHN2 & 0.99779 & 0.99794 \\
\hline KHEGT & 1.00128 & 1.00120 \\
\hline KHFN & 1.00026 & 1.00024 \\
\hline KHWF & 0.99312 & 0.99358 \\
\hline
\end{tabular}

Temperature Rise CorrectionFactor Tabel 5 Temperature Rise Correction Factor

\begin{tabular}{|l|l|l|}
\hline \multirow{2}{*}{$\begin{array}{c}\text { Correction } \\
\text { Factor }\end{array}$} & \multicolumn{2}{|c|}{ Thrust Rating } \\
\cline { 2 - 3 } & $\mathbf{2 6 3 0 0} \mathbf{~ l b s}$ & $\mathbf{2 7 3 0 0} \mathrm{lbs}$ \\
\hline $\mathrm{T}_{2}$ & $85.298^{\circ} \mathrm{F}$ & \multicolumn{1}{|c|}{$73.004^{\circ} \mathrm{F}$} \\
\hline Humidity & $\begin{array}{l}99.6 \\
\text { grains } / \mathrm{lb}\end{array}$ & $\begin{array}{l}92.9 \\
\text { grains } / \mathrm{lb}\end{array}$ \\
\hline T RISE & $25.545^{\circ} \mathrm{F}$ & $23.563^{\circ} \mathrm{F}$ \\
\hline
\end{tabular}

Exponent Factor

Tabel 6 Exponent Factor

\begin{tabular}{|c|c|c|}
\hline \multirow[b]{2}{*}{$\begin{array}{l}\text { Correction } \\
\text { Factor }\end{array}$} & \multicolumn{2}{|c|}{ Thrust Rating } \\
\hline & $\begin{array}{l}26300 \\
\text { lbs }\end{array}$ & $\begin{array}{l}27300 \\
\text { lbs }\end{array}$ \\
\hline N1R2XX & 5067.13 & 5220.31 \\
\hline N1 MEAS & 5209.6 & 5307.58 \\
\hline EXPN1 & 0.4526 & 0.4204 \\
\hline EXPN2 & 0.500 & 0.500 \\
\hline EXPN2C & 0.357 & 0.357 \\
\hline EXPT3 & 0.8461 & 0.8377 \\
\hline EXPN2HD & 0.5000 & 0.5000 \\
\hline EXPN2CHD & 0.3570 & 0.3570 \\
\hline EXPEGT & 0.8857 & 0.887 \\
\hline EXPWF & 0.650 & 0.650 \\
\hline EXPEGTHD & 0.8852 & 0.8870 \\
\hline$\theta_{2 \mathrm{HD}}$ & 1.052056 & 1.052056 \\
\hline
\end{tabular}


Jurnal Teknologi Kedirgantaraan, Vol, VII No. 1, Januari 2022, P-ISSN 2528-2778, E-ISSN 2684-9704 https://doi.org/ 10.35894/jtk.v7i1

Inlet Condensation CorrectionFactor

Tabel 7 Inlet Condensation Correction Factor

\begin{tabular}{|l|l|l|}
\hline \multirow{2}{*}{$\begin{array}{c}\text { Correction } \\
\text { Factor }\end{array}$} & \multicolumn{2}{|c|}{ Thrust Rating } \\
\cline { 2 - 3 } & $\mathbf{2 6 3 0 0}$ lbs & $\mathbf{2 7 3 0 0}$ lbs \\
\hline N1K & 5072 & 5227 \\
\hline N1R & 5059 & 5202 \\
\hline N1KFAC & -0.0001 & -0.0002 \\
\hline N2KFAC & 0 & 0 \\
\hline TKFAC & -0.0002 & -0.0002 \\
\hline WFFAC & -0.0001 & -0.0001 \\
\hline AKFAC & 0 & 0 \\
\hline KCONDN1 & 0.99744 & 0.99529 \\
\hline KCONDN2 & 1.00000 & 1.00000 \\
\hline KCONDT & 0.99489 & 0.99529 \\
\hline KCONDW & 0.99744 & 0.99764 \\
\hline KCONDA & 1.00000 & 1.00000 \\
\hline
\end{tabular}

Adjustment due to test cell installation effect

Tabel 8 Adjustment due to test cell installation effect

\begin{tabular}{|l|l|l|}
\hline \multirow{2}{*}{$\begin{array}{c}\text { Correction } \\
\text { Factor }\end{array}$} & \multicolumn{2}{|c|}{ Thrust Rating } \\
\cline { 2 - 3 } & $\mathbf{2 6 3 0 0}$ lbs & $\mathbf{2 7 3 0 0}$ Ibs \\
\hline N1R & 5059 & 5202 \\
\hline FN ADJ & 1.0005 & 1.0001 \\
\hline WF ADJ & 0.9982 & 0.9981 \\
\hline N2 ADJ & 1.0000 & 1.0000 \\
\hline EGT ADJ & 0.9982 & 0.9992 \\
\hline W2 ADJ & 1.0007 & 1.0004 \\
\hline
\end{tabular}

Facility Modifiers Correction Factor

Tabel 9 Facility Modifiers Correction Factor

\begin{tabular}{|l|c|l|}
\hline \multirow{2}{*}{$\begin{array}{c}\text { Correction } \\
\text { Factor }\end{array}$} & \multicolumn{2}{|c|}{ Thrust Rating } \\
\cline { 2 - 3 } & $\mathbf{2 6 3 0 0} \mathbf{~ l b s}$ & $\mathbf{2 7 3 0 0}$ lbs \\
\hline FMFN & 1.022666 & 1.021995 \\
\hline FMEGT & 1.006553 & 1.005245 \\
\hline FMWF & 1.0122211 & 1.0081484 \\
\hline FMN2 & 1.001592 & 1.001213 \\
\hline FMW2R & 1.007903 & 1.007088 \\
\hline
\end{tabular}

Perfomance Derivatives Correction Factor

Tabel 10 Perfomance Derivatives Correction Factor

\begin{tabular}{|c|l|l|}
\hline \multirow{2}{*}{$\begin{array}{c}\text { Correction } \\
\text { Factor }\end{array}$} & \multicolumn{2}{|c|}{ Thrust Rating } \\
\cline { 2 - 3 } & $\mathbf{2 6 3 0 0}$ lbs & $\mathbf{2 7 3 0 0}$ lbs \\
\hline FN Delta & -194.48 & -136.08 \\
\hline EGT Delta & -0.5662 & 2.0544 \\
\hline N2 Delta & -17.16 & 6 \\
\hline W2 Delta & -2.64 & -0.54 \\
\hline $\begin{array}{c}\text { WFDR } \\
\text { Delta }\end{array}$ & -109.12 & -123.66 \\
\hline
\end{tabular}

EGT Shunt Values CorrectionFactor

Tabel 11 EGT Shunt ValuesCorrection Factor

\begin{tabular}{|c|l|l|}
\hline Correction & \multicolumn{2}{|c|}{ Thrust Rating } \\
\cline { 2 - 3 } Factor & $\mathbf{2 6 3 0 0}$ lbs & $\mathbf{2 7 3 0 0}$ lbs \\
\hline $\begin{array}{c}\text { EGT } \\
\text { KSHUNT1 }\end{array}$ & 1.0 & 1.0 \\
\hline $\begin{array}{c}\text { EGT } \\
\text { KSHUNT2 }\end{array}$ & 0.0 & 0.0 \\
\hline
\end{tabular}

Setelah semua parameter yang diperlukan sudah lengkap, selanjutnya melakukan perhitungan performa menggunakan formula yang terdapat pada Engine Shop Manual - Test 003 Engine Acceptance Test CFM56-7B.

\subsection{Analisis Hasil Perhitungan Performa}

Dari perhitungan performa engine CFM56-7B pada kedua konfigurasi. Didapatkan beberapa hasil yang selanjutnya akan dianalisis, berikut adalah tabel hasilperhitungan:

Berdasarkan Tabel 12, thrust dari kedua konfigurasi engine tersebut melampaui thrust yang harus dicapai. Untuk engine dengan thrust rating 26300 lb mencapai 26557 lbs mengalami penurunan performa dibandingkan dengan hasil tes pertama dan engine dengan thrust rating $27300 \mathrm{lb}$ mencapai 27896 Ibs mengalami peningkatan performa dibandingkan dengan hasil tes pertama. Sehingga 
Jurnal Teknologi Kedirgantaraan, Vol, VII No. 1, Januari 2022, P-ISSN 2528-2778, E-ISSN 2684-9704 https://doi.org/ 10.35894/jtk.v7i1

Tabel 12 Parameter hasil perhitungan

\begin{tabular}{|c|c|c|c|c|}
\hline \multirow{3}{*}{ Parameter } & \multicolumn{4}{|c|}{ Thrust Rating } \\
\hline & \multicolumn{2}{|c|}{$26300 \mathrm{lbs}$} & \multicolumn{2}{|c|}{$27300 \mathrm{lbs}$} \\
\hline & $1^{\text {th }}$ Test & Perhitungan & $1^{\text {tet }}$ Test & Perhitungan \\
\hline FNK (lbs) & & 26145 & & 27426 \\
\hline FNK1 (lbs) & & 26738 & & 28029 \\
\hline FNK2(lbs) & & 26751 & & 28031 \\
\hline FNK3 (lbs) & 26588 & 26557 & 27668 & 27896 \\
\hline Thrust Margin (\%) & & 0.977 & & 2.183 \\
\hline N1K (rpm) & 5081 & 5072 & 5229 & 5227 \\
\hline N1R (rpm) & 5159 & 5059 & 5159 & 5202 \\
\hline N1KRM (rpm) & & 5069 & & 5206 \\
\hline WFK (lb/hr) & & 10399.25 & & 11230.22 \\
\hline WFK1 (lb/hr) & & 10526.34 & & 11321.73 \\
\hline WFK2 (lb/hr) & & 10507.39 & & 11300.22 \\
\hline WFK3 (lb/hr) & & 10398.27 & & 11176.56 \\
\hline SFC Margin (\%) & & -5.77 & & -3.81 \\
\hline EGTK $\left({ }^{\circ} \mathrm{C}\right)$ & & 821.3 & & 849.4 \\
\hline EGTK1 $\left({ }^{\circ} \mathrm{C}\right)$ & & 828.5 & & 855.3 \\
\hline EGTK2 $\left({ }^{\circ} \mathrm{C}\right)$ & & 826.5 & & 854.4 \\
\hline EGTK3 $\left({ }^{\circ} \mathrm{C}\right)$ & & 825.9 & & 856.4 \\
\hline N2K atau N2R (rpm) & & 14377 & & 14474 \\
\hline N2K1(rpm) & & 14400 & & 14492 \\
\hline $\mathrm{N} 2 \mathrm{~K} 2(\mathrm{rpm})$ & & 14400 & & 14492 \\
\hline $\mathrm{N} 2 \mathrm{~K} 3(\mathrm{rpm})$ & & 14398 & & 14498 \\
\hline W2AR $(\mathrm{lb} / \mathrm{s})$ & & 772.48 & & 790.14 \\
\hline $\mathrm{W} 2 \mathrm{~K} 1(\mathrm{lb} / \mathrm{s})$ & & 778.58 & & 795.74 \\
\hline $\mathrm{W} 2 \mathrm{~K} 2(\mathrm{lb} / \mathrm{s})$ & & 779.125 & & 796.06 \\
\hline W2K3 (lb/s) & & 776.485 & & 795.52 \\
\hline OCPR & & 27.13 & & 28.53 \\
\hline CTR & & 2.83 & & 2.89 \\
\hline EGT Hot Day $\left({ }^{\circ} \mathrm{C}\right)$ & 841 & 876.42 & 869 & 908.4 \\
\hline EGTHD Margin $\left({ }^{\circ} \mathrm{C}\right)$ & & 41.58 & & 15.6 \\
\hline $\mathrm{N} 2 \mathrm{CC} 3(\mathrm{rpm})$ & 14625 & 14661.23 & 14715 & 14763.06 \\
\hline N2HD Margin (\%) & & 0.857 & & 0.892 \\
\hline
\end{tabular}

menghasilkan nilai thrust margin yang positif. Thrust margin merupakan selisih antara thrust hasil perhitungan dengan thrust rate yang harus dicapai.

Pada Gambar 4 menunjukkan perbandingan hasil tes pertama dengan hasil perhitungan. Dari grafik tersebut dapat dihitung presentasi perubahan nilai thrust. Pada thrust rating 26300 lbs mengalami penurunan sebesar $0.117 \%$, sedangkan pada thrust rating $27300 \mathrm{lbs}$ mengalami peningkatan thrust sebesar $0.824 \%$.

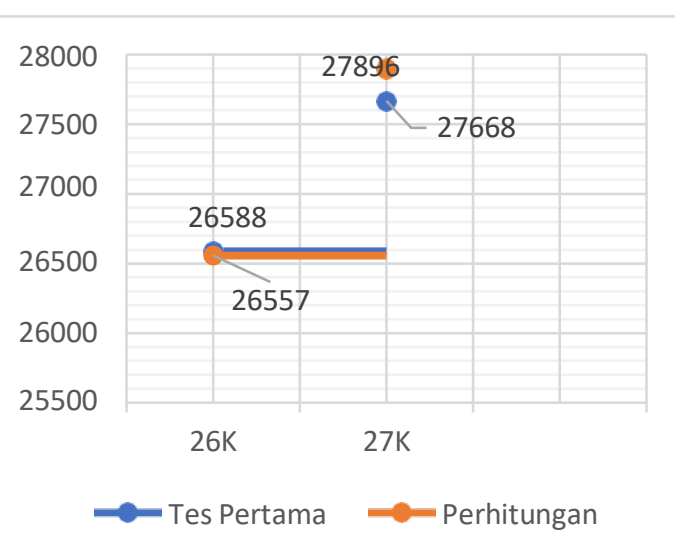

Gambar 4 Perbandingan thrust hasil tes pertama dengan hasil perhitungan 
Pada Tabel 12 tercantum Nilai SFC (Specific Fuel Consumption). SFC menyatakan berapa banyak bahan bakar yang diperlukan engine untuk menghasilkan gaya dorong. Pada rating 26300 Ibs nilai SFC Margin mencapai $5.77 \%$, sedangkan ada rating $27300 \mathrm{lbs}$ nilai SFC Margin mencapai $-3.81 \%$. Kedua rating mendapatkan hasil yang negatif terhadap standar $0.0 \%$. maka, dapat diartikan bahwa efisiensi engine telah berkurang dalam konteks SFC, terutama pada rating 26300 Ibs karena mendapatkan hasil negatif yang cukup besar.

Berdasarkan nilai Exhaust Gas Temperature (EGT) yang dihasilkan oleh kedua konfigurasi rating tersebut, kedua enginemasih dalam kondisi yang layak karena nilai EGT tidak melebihi EGT Redline yaitu $918{ }^{\circ} \mathrm{C}$ (pada Tabel 2.2) untuk rating $26300 \mathrm{lbs}$ dengan margin $41.58{ }^{\circ} \mathrm{C}$ dan $924^{\circ} \mathrm{C}$ (pada Tabel 2.3) untuk rating $27300 \mathrm{lbs}$ dengan margin $15.6^{\circ} \mathrm{C}$. Nilai EGT semakin meningkat dibandingkan dengan hasil tes pertama. Grafik perbandingan nilai EGT saat tes pertama dengan hasil perhitungan ditunjukkan padaGambar 5. Pada grafik tersebut dapat dihitung nilai presentasi perubahan EGT. Pada thrust rating 26300 Ibs mengalami peningkatan sebesar $4.2 \%$, sedangkan pada thrust rating $27300 \mathrm{lbs}$ mengalami peningkatan EGT sebesar $4.5 \%$.

Core rotation (N2) merupakan salah satu parameterpenentu kualitas engine. Dari hasil perhitungan performa takeoff engine CFM56-7B di atas, konfigurasi engine baik rating 26300 lbs maupun rating 27300 lbs dapat dikatakan menghasilkan performa yang tinggi karena nilai N2 tidak melebihi N2 Redline. NilaiN2 sebesar $14375.85 \mathrm{rpm}$ untukengine pada thrust rating 26300 lbs dengan nilai margin sebesar $0.857 \%$ dan
$14438.49 \mathrm{rpm}$ untuk engine pada thrust rating 27300 lbs dengan nilai margin sebesar $0.892 \%$.

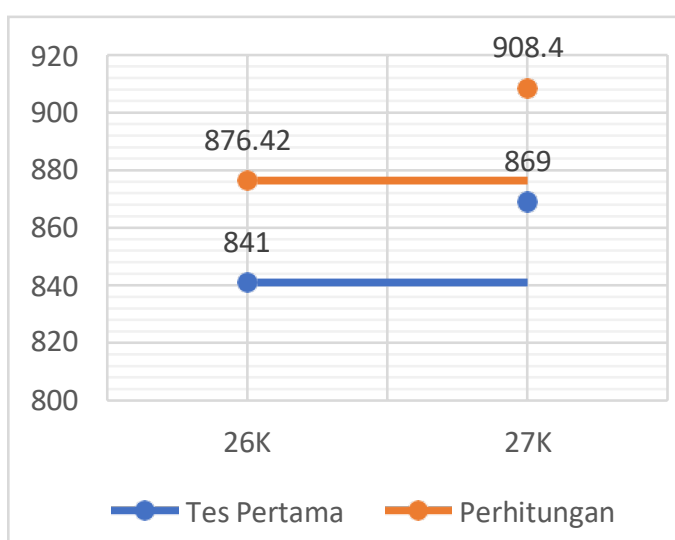

Gambar 5 Perbandingan EGT hasil tes pertama dengan hasil perhitungan

\section{Kesimpulan}

Hasil perhitungan performa takeoff untuk engine CFM56-7B dengan konfigurasi thrust rating 26300 lbs dan thrust rating 27300 lbs berdasarkan formula dari Engine Shop Manual - Test 003 - Engine Acceptance Test adalah sebagai berikut: Pertama, berdasarkan hasil perhitungan thrust kedua konfigurasi engine mendapatkan hasil thrust marginyang positif yaitu $0.977 \%$ dan $2.183 \%$. Artinya, kedua konfigurasi engine tersebut memenuhi persyaratan thrust. Kedua, Nilai SFC margin yang didapatkan untukthrust rating $26300 \mathrm{lbs}$ adalah $-5.77 \%$ dan $-3.81 \%$ untuk thrust rating 27300 lbs. Nilai SFC margin memang lebih rendah dari standar $0.0 \%$ namun masih dalam batasaman. Ketiga, Nilai EGT margin kedua engine positif, maka engine dapat dikatakan baik. Pada thrust rating 26300 lbs mengalami kenaikan EGT sebesar $4.2 \%$ sedangkan pada 27300 lbs mengalami kenaikan EGT sebesar4.5\%. Keempat, Nilai core speed engine dengan thrust rating 26300 lbs yaitu $14661.23 \mathrm{rpm}$ dengan margin 
Jurnal Teknologi Kedirgantaraan, Vol, VII No. 1, Januari 2022, P-ISSN 2528-2778, E-ISSN 2684-9704

https://doi.org/ 10.35894/jtk.v7i1

$0.857 \%$ dan $14763.06 \mathrm{rpm}$ dengan margin $0.892 \%$ pada engine dengan thrust rating 27300 lbs. Kedua engine masih dalam performa yang baik, karena nilai N2 tidak melebihi target (N2 Redline). Sehingga, perbandingan performa saat takeoff pada engine CFM56- 7B thrust rating 26300 lbs dan 27300 Ibs dari hasil perhitungan dan pembahasan menyatakan bahwa rating 26300 lbs lebih unggul dalam segi Exhaust Gas Temperature (EGT), sedangkan untuk rating 27300 lbs unggul dalam Thrust, Specific Fuel Consumption (SFC) dan Core Speed (N2 Speed).

\section{DAFTAR PUSTAKA}

[1] Saravanamuttoo, $\mathrm{HIH}$,Cohen, $\mathrm{H}$. and Rogers, GFC., 2001, Gas Turbine Theory $5^{\text {th }}$ ed. London: Pearson Education, Ltd.

[2] Moran, M.J. and Shapiro, H.N., 2006, Fundamentals of Engineering

Thermodynamics $5^{\text {th }}$ ed. Inggris: John Wiley \& Sons, Inc.

[3] Storm, R., Skor, M., Koch, L.D., Benson, T., and Galica, C., 2007, A NASA Guide to Engine. Laura Becker. Washington, D.C.:NASA gov. 1996,

[4] CFM56, https://www.cfmaeroengine s.com/engines/cfm56/, diakses pada 23 September2019.

[5] MTU Maintenance Hannover, 2000, CFM56-7B General Familiarization. CFM56-7B, https://www. safran-aircraftengines.com/commercialengines/single-aisle- commercialjets/cfm56/cfm56-7b, diakses pada 23 September2019.

[6] CFM International, 2017, CFM56$7 B$ Engine Shop 003 - Engine Acceptance Test.
[7] Ackert, S., 2011, Engine Maintenance Concepts for Financiers. Aircraft Monitor 2nd ed.

[8] CFM International, 2015, CFM56-7B S/B 72-0003 12nd Revision. 